\title{
FURTHER ASSESSMENT OF CARDIOLIPIN ANTIGEN BY PARALLEL TESTING AGAINST STANDARD ANTIGEN IN ROUTINE WASSERMANN REACTIONS* ${ }^{*}$
}

\author{
BY \\ SIDNEY SHAW \\ From the Department of Clinical Pathology, Charing Cross Hospital and Medical School, London
}

In a previous communication (Shaw, 1955), I referred to several papers concerning the value of cardiolipin antigen in complement-fixation and flocculation tests. The majority of workers have reported increased sensitivity and specificity with this antigen, which has also been recommended to obtain reproducible results in various laboratories in different countries.

At that time, I compared the results of over 7,000 complement-fixation tests using cardiolipin and crude heart antigens in parallel tests. The results showed that cardiolipin antigen gave increased sensitivity, especially with early syphilis and treated syphilis, but gave more non-specific reactions which were most evident with antenatal sera. In this previous series, the crude heart antigen, designated as standard antigen, was used at a dilution of $1 / 15$ in saline as in Harrison and Wyler's technique. The cardiolipin antigen was Burroughs Wellcome Whitechapel Clinic Formula, used at optimum titre.

\section{Previous Experiments}

Cardiolipin antigen has been reported on recently as less satisfactory by other workers, including the following:

Price and Wilkinson (1952) compared both antigens at optimum titre in the Wassermann reaction. They found that cardiolipin antigen was more sensitive in tests on sera from treated syphilitics but that it gave more nonspecific reactions with routine sera.

Price (1954) compared a further series in this way and obtained more non-specific reactions with routine unselected sera. He also performed parallel tests using both antigens in precipitation tests, and obtained a much higher incidence of non-specific reactions with cardiolipin antigen on both routine and problem sera.

Nelson and Martin (1954), in a series of tests on 1,341 sera, reported false positive complement-fixation tests on twenty sera with cardiolipin antigen, and on sixteen sera with standard antigen; in the same series the Kahn tests gave only four false positives.

* Received for publication August 3, 1956

+ Paper read at First International Symposium on the Venereal Diseases and Treponematoses, Washington, D.C., May, 1956.
Andujar and Mazurek (1956) examined sera of old syphilitic patients. In the complement-fixation tests, cardiolipin antigen produced a positive result in the majority of patients whose previous complementfixation test, using the older type of antigen, had been negative for some years. They refer to this as an anamnestic reaction and point out that with cardiolipin antigen, sera from patients once syphilitic are always syphilitic.

\section{Present Series}

In this present series, tests were carried out from February, 1955, to February, 1956; they were performed in parallel but both antigens were used at optimum titre. This has given a truer comparison, and it was also noted that, with both antigens at optimum titre, they almost invariably gave identical complement-titration results and were little more destructive of complement than was normal saline.

\section{Results}

Altogether 3,588 routine hospital sera were examined in this way. The results were compared and sub-divided into tests excluding antenatal sera, and tests on antenatal sera as shown in the following Tables.

Table I shows a comparison of the results of tests on 1,373 sera (excluding antenatal). There was

TABLE I

1,373 SERA EXCLUDING ANTENATAL SERA

\begin{tabular}{|c|c|c|c|c|c|}
\hline \multirow{2}{*}{\multicolumn{4}{|c|}{ Results }} & \multicolumn{2}{|c|}{ Sera } \\
\hline & & & & \multirow{2}{*}{$\begin{array}{r}\text { No. } \\
36 \\
12 \\
1,258\end{array}$} & \multirow{2}{*}{$\frac{\text { Per cent. }}{95 \cdot 1}$} \\
\hline Agree & .. & $\begin{array}{l}\text { Both }+\ldots \\
\text { Both } \pm \ldots \\
\text { Both }=\ldots\end{array}$ & $\begin{array}{l}. \\
\therefore \\
.\end{array}$ & & \\
\hline \multirow{2}{*}{ Disagree } & \multirow{2}{*}{. } & $\begin{array}{ll}\mathbf{C}+ & \mathbf{S}= \\
\mathbf{C} \pm & \mathbf{S}= \\
\mathbf{C}+ & \mathbf{S} \pm\end{array}$ & $\begin{array}{l}. \\
\cdots \\
\cdots\end{array}$ & $\begin{array}{l}12 \\
31 \\
23\end{array}$ & 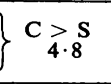 \\
\hline & & $\begin{array}{ll}\mathbf{S}+ & \mathbf{C}- \\
\mathbf{S} \pm & \mathbf{C}= \\
\mathbf{S}+ & \mathbf{C} \pm\end{array}$ & $\begin{array}{l}. \\
\cdots\end{array}$ & $\begin{array}{c}\mathrm{Nil} \\
1 \\
\mathrm{Nil}\end{array}$ & $\left\{\begin{array}{l}S>C \\
0.1\end{array}\right.$. \\
\hline \multicolumn{3}{|c|}{ Total Tested $\quad .}$. & .. & 1,373 & 100 \\
\hline
\end{tabular}


agreement in $95 \cdot 1$ per cent. and disagreement with cardiolipin antigen giving some result when standard antigen gave a negative or doubtful result in 4.8 per cent., standard antigen giving a greater reaction than cardiolipin antigen in only $0 \cdot 1$ per cent.

Among these 1,373 routine sera (Table II) were 92 from known cases of syphilis (some were considered as syphilis when the serological results were taken in conjunction with their histories and clinical findings). Only five of these were new infections, and the remainder were old or treated cases of syphilis. The results show agreement between both antigens in 44 sera and disagreement with cardiolipin antigen giving a greater reaction than standard antigen in 48 sera. Cardiolipin was, therefore, again shown to be a more sensitive antigen in the complementfixation test on syphilitic sera.

\section{TABLE II}

FROM 1,373 SERA EXCLUDING ANTENATAL SERA, AND INCLUDING 92 KNOWN CASES OF SYPHILIS

\begin{tabular}{|c|c|c|c|c|c|}
\hline \multirow{2}{*}{\multicolumn{4}{|c|}{ Results }} & \multicolumn{2}{|c|}{ Sera } \\
\hline & & & & \multirow{2}{*}{$\begin{array}{r}\text { No. } \\
36 \\
8\end{array}$} & Totals \\
\hline Agree & . & $\begin{array}{l}\text { Both }+\ldots \\
\text { Both }-\ldots\end{array}$ & 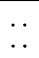 & & 44 \\
\hline \multirow{2}{*}{ Disagree } & \multirow{2}{*}{. } & $\begin{array}{l}\mathbf{C}+\mathbf{S}- \\
\mathbf{C}=\mathbf{S}- \\
\mathbf{S}+\end{array}$ & $\begin{array}{l}\ldots \\
\cdots \\
.\end{array}$ & $\begin{array}{l}10 \\
17 \\
21\end{array}$ & $\mathrm{C}_{48}>\mathrm{S}$ \\
\hline & & $\begin{array}{ll}\mathbf{S}+ & \mathbf{C}- \\
\mathbf{S}+ & \mathbf{C}- \\
\mathbf{S}+ & \mathbf{C}\end{array}$ & $\begin{array}{l}\ldots \\
\cdots\end{array}$ & $\begin{array}{l}\mathrm{Nil} \\
\mathrm{Nil} \\
\mathrm{Nil}\end{array}$ & $\mathrm{S} \underset{\mathrm{Nil}}{>} \mathrm{C}$ \\
\hline \multicolumn{3}{|c|}{ Total Specific Sera .. } & $\ldots$ & 92 & 92 \\
\hline
\end{tabular}

Among these 1,373 sera, 23 gave results considered as non-specific (Table III). Although some reaction was given with either antigen, in none of these cases were there positive histories or clinical findings, and the Kahn tests were negative in all but one. Many of these sera were re-examined by further parallel complement-fixation tests with similar or negative results. This Table shows the results of these non-specific reactions.

TABLE III

\begin{tabular}{|c|c|c|c|c|c|}
\hline \multicolumn{5}{|c|}{ Results } & Sera \\
\hline ree & Both $\pm \ldots$ & .. & .. & .. & 4 \\
\hline \multirow{2}{*}{ sagree } & $\begin{array}{l}\mathbf{C}+\mathbf{S}- \\
\mathbf{C} \neq \mathbf{S}- \\
\mathbf{C}=\mathbf{S}\end{array}$ & $\begin{array}{l}. \\
. \\
.\end{array}$ & $\begin{array}{l}. \\
\ldots\end{array}$ & $\begin{array}{l}. \\
\ldots\end{array}$ & $\begin{array}{r}2 \\
14 \\
2\end{array}$ \\
\hline & $\mathbf{S} \pm \mathrm{C}-$ & .. & .. & .. & 1 \\
\hline \multicolumn{2}{|c|}{ Total Non-Specific .. } & .. & .. & .. & 23 \\
\hline
\end{tabular}

Table IV shows the incidence of these non-specific reactions compared with routine sera excluding antenatal sera. It is seen that cardiolipin antigen gave 1.6 per cent. non-specific reactions, and standard antigen only 0.5 per cent.

TABLE IV

FROM 1,373 SERA EXCLUDING ANTENATAL SERA NON-SPECIFIC REACTIONS COMPARED

\begin{tabular}{llll|cc|c}
\hline & \multirow{2}{*}{ Antigen } & & & Non-Specific Reactions \\
\cline { 4 - 6 } & & & & No. & Per cent. \\
\hline Cardiolipin &. &. &. &. & 22 & 1.6 \\
\hline Standard &. & $\ldots$ &. &. & 7 & 0.5 \\
\hline
\end{tabular}

Table V compares the results of tests on 2,215 routine antenatal sera. A high incidence of doubtful reactions is seen with cardiolipin antigen. In these cases, there were negative histories and clinical findings, and negative Kahn tests in all but one. Many tests were repeated on further specimens with the same or negative results; they were, therefore, considered as non-specific reactions.

TABLE V

2,215 ANTENATAL SERA

\begin{tabular}{|c|c|c|c|c|c|}
\hline \multirow{2}{*}{\multicolumn{4}{|c|}{ Results }} & \multicolumn{2}{|c|}{ Sera } \\
\hline & & & & \multirow{2}{*}{$\begin{array}{r}\text { No. } \\
4+ \\
6= \\
2,119=\end{array}$} & Per cent. \\
\hline Agree & . & $\begin{array}{l}\text { Both }+\cdots \\
\text { Both } \pm \cdots \\
\text { Both }-\cdots\end{array}$ & $\begin{array}{l}\ldots \\
\cdots \\
\cdots\end{array}$ & & $96 \cdot 1$ \\
\hline \multirow{2}{*}{ Disagree } & \multirow{2}{*}{$\cdots$} & $\begin{array}{l}\mathbf{C}+\mathbf{S}- \\
\mathbf{C} \pm \mathbf{S}- \\
\mathbf{C}+\mathbf{S}=\end{array}$ & $\begin{array}{l}\ldots \\
\cdots\end{array}$ & $\begin{array}{r}10= \\
74= \\
2=\end{array}$ & \} $\begin{array}{r}C>S \\
3 \cdot 9\end{array}$ \\
\hline & & $\begin{array}{l}\mathbf{S}+\mathbf{C}- \\
\mathbf{S}+\mathbf{C}= \\
\mathbf{S}+\mathbf{C}=\end{array}$ & $\begin{array}{l}\ldots \\
\therefore \\
\cdots\end{array}$ & $\begin{array}{l}\mathrm{Nil} \\
\mathrm{Nil} \\
\mathrm{Nil}\end{array}$ & \}$\quad \begin{array}{l}S>C \\
N i l\end{array}$ \\
\hline \multicolumn{3}{|c|}{ Total Tested.. } & .. & 2,215 & 100 \\
\hline
\end{tabular}

+ Kahn Positive.

- Kahn Negative

= Kahn Negative except for one case of treated syphilis in each group

Table VI gives the compared incidence of nonspecific reactions among the 2,215 antenatal sera examined. Cardiolipin antigen gave 4 per cent. non-specific reactions, and standard antigen only $0 \cdot 3$ per cent.

TABLE VI

2,215 ANTENATAL SERA NON-SPECIFIC REACTIONS COMPARED

\begin{tabular}{|c|c|c|c|c|c|c|}
\hline \multirow{2}{*}{\multicolumn{5}{|c|}{ Antigen }} & \multicolumn{2}{|c|}{ Non-Specific Reactions } \\
\hline & & & & & \multirow{2}{*}{$\frac{\text { No. }}{89}$} & \multirow{2}{*}{$\begin{array}{c}\text { Per cent. } \\
4 \cdot 0\end{array}$} \\
\hline Cardiolipin & . & . & . & $\cdots$ & & \\
\hline Standard & .. & .. & .. & . & 6 & $0 \cdot 3$ \\
\hline
\end{tabular}

\section{Conclusions}

From the above compared results, it may be concluded that cardiolipin antigen is undoubtedly more sensitive in the complement-fixation test. This 
increased sensitivity is of value in detecting early syphilis; it is also especially sensitive in old and treated cases.

With the increased use of antibiotics for many conditions, partial treatment of undiagnosed syphilis may be unwittingly given; the sensitive cardiolipin antigen is more likely to give a positive result, and to be of assistance in the diagnosis of syphilis in such cases. On the other hand, this increased sensitivity is sometimes a disadvantage. After satisfactory treatment of syphilis, cardiolipin antigen frequently gives a positive or doubtful result when the standard antigen test has become negative and when the condition is clinically cured.

The chief drawback to the use of cardiolipin antigen in the complement-fixation test is the increase in non-specific reactions, which is most evident with antenatal serà. In this Group, I no longer report a doubtful cardiolipin result when the standard antigen test and Kahn test are both negative.

In this laboratory, for over 3 years now, all Wassermann reactions have been performed in duplicate, using both types of antigen; any doubtful or conflicting results are then assessed after a Kahn test. In this way, a satisfactory interpretation can be given by paying particular attention to the more sensitive result of the cardiolipin antigen and the more specific result of the standard antigen.

\section{Summary}

Parallel complement-fixation tests using cardiolipin and standard antigen, both at optimum titre, were determined on 3,588 routine hospital sera.

Cardiolipin antigen showed increased sensitivity, especially in old cases of syphilis but there was loss in specificity. Non-specific reactions were particularly marked with antenatal sera.

I wish to thank Miss G. Pierpoint for her valuable technical assistance, and also my secretary, Miss G. Rayner.

\section{REFERENCES}

Andujar, J. J., and Mazurek, E. E. (1956). Amer. J. clin. Path., 26, 368. Nelson, M. G., and Martin, E. P. (1954). Irish J. med. Sci., 6th ser., No. 341, p. 218

Price, I. N. O. (1954). British Journal of Venereal Diseases, 30, 210

and Wilkinson, A. E. (1952). Ibid., 28, 16.

Shaw, S. (1955). Ibid., 31, 86. 